\title{
Tingkat Difusi-Adopsi Inovasi Biogas di Kecamatan Lembang, Kabupaten Bandung Barat
}

\section{Biogas Diffusion and Adoption in Lembang Sub District, Bandung Barat District}

\author{
Nurul Dwi Novikarumsari ${ }^{1}$, Siti Amanah ${ }^{2}$, Basita Ginting Sugihen ${ }^{2}$ \\ ${ }^{1}$ Program Studi Ilmu Penyuluhan Pembangunan, \\ Sekolah Pascasarjana, Intitut Pertanian Bogor, Bogor. \\ ${ }^{2}$ Departemen Sains Komunikasi dan Pengembangan Masyarakat, \\ Fakultas Ekologi Manusia, Institut Pertanian Bogor, Bogor.
}

\begin{abstract}
This study aims to analyse the household characteristics of dairy farmer, perception of biogas innovation, access of information, the meeting with extension workers and factors affecting biogas diffusion and adoption in Lembang Sub District. Lembang Sub District has a potential of 4149 dairy farmer households as prospected biogas adopters. Suntenjaya and Cibodas villages were selected as the research sites. All of the population member (266 households) were the research respondents. Questionnaires consist of four independent variables include dairy farmers characteristic, perception of biogas, access of information, and the meeting with extension workers were used to collect primary data. Rank Spearman correlation test was used to analyse the data. Research results shows that motivation, complexity, compatibility, and observability has positive correlation with speed of adoption; and dairy farmers experiences, relative advantage, and and triability has positive correlation with diffusion; the access of information and meeting with extension workers do not correlate with biogas diffusion-adoption since the farmers has involved in the biogas program from an international foundation.
\end{abstract}

Keywords: diffusion, adoption, biogas, perception, inovation

Abstrak

Penelitian bertujuan untuk menganalisis karakteristik RTPSP, persepsi tentang sifat inovasi, akses terhadap informasi, frekuensi pertemuan dengan penyuluh biogas, dan faktor yang berhubungan dengan tingkat difusi-adopsi inovasi di Kecamatan Lembang. Terdapat 4149 Rumah Tangga Peternak Sapi Perah (RTPSP) yang berpotensi sebagai adopter. Desa Suntenjaya dan Desa Cibodas dipilih sebagai lokasi penelitian. Responden dalam penelitian ini sebanyak 266 RTPSP (sensus). Kuesioner terdiri dari empat peubah bebas yaitu karakteristik RTPSP, persepsi tentang sifat biogas, akses terhadap informasi, dan frekuensi pertemuan dengan penyuluh biogas. Analisis data dilakukan dengan menggunakan Rank Spearman. Simpulan penelitian ini adalah motivasi, keuntungan relatif, kompleksitas, kompatibilitas dan observabilitas memiliki hubungan positif nyata dengan kecepatan adopsi; lama beternak, keuntungan relatif dan triabilitas memiliki hubungan positif nyata dengan penyebaran sedangkan akses terhadap informasi dan frekuensi pertemuan dengan penyuluh biogas tidak memiliki hubungan positif nyata dengan difusi-adopsi. Peternak terlibat dalam program biogas yang disponsori lembaga swadaya internasional.

Kata Kunci: difusi, adopsi, biogas, persepsi, inovasi

\section{Pendahuluan}

Teknologi biogas telah berkembang sejak tahun 1700. Biogas dihasilkan dari berbagai sumber, salah satunya yang berasal dari feces hewan (Abbasi et al., 2011). Indonesia mulai mengadopsi teknologi biogas dari feces sapi perah pada awal tahun 1970-an di Jawa Timur. Pada tahun 1982 pemerintah membantu penambahan unit biogas dengan Program Bantuan Presiden (BANPRES). Setelah pengembangan biogas di daerah Pujon berhasil, dilanjutkan pengembangan unit biogas di Kediri yang dilakukan pada tahun 1983. Sekitar tahun 2000 dikembangkan reaktor biogas skala kecil (rumah tangga) dengan konstruksi sederhana dan terbuat dari plastik, kemudian teknologi biogas berkembang kembali sejak tahun 2006 ketika terjadi peningkatan harga bahan bakar minyak (Wahyuni, 2011).

Selain di Jawa Timur, berkembang pula biogas di Kecamatan Lembang, yaitu di Desa Cibodas dan Desa Suntenjaya, hingga saat ini sekitar $39,4 \%$ dari jumlah rumahtangga di dua desa tersebut yang telah menerapkan biogas dan diharapkan biogas dapat terdifusi dalam sistem sosial. Biogas merupakan inovasi dari segi pertanian dan energi terbarukan. Sebelum diadopsi dan terdifusi, peternak melakukan

\footnotetext{
${ }^{1}$ Korespondensi penulis

E-mail: nuruldwinovikarumsari@ymail.com
} 
penilaian tentang sifat inovasi meliputi keuntungan relatif, kompatibilitas, kompatibilitas, triabilitas dan observabilitas (Rogers 2003). Sejalan dengan hal tersebut, Wei Qu et al. (2013) menyebutkan bahwa faktor-faktor yang dapat mempengaruhi penerapan biogas yaitu persepsi tentang inovasi biogas, sedangkan Humayun K (2013), mengemukakan bahwa faktor lain yaitu tingkat pendidikan dan tingkat pendapatan memengaruhi penerapan biogas.

Penelitian ini bertujuan untuk: (1) menganalisis karakteristik Rumah Tangga Peternak Sapi Perah (RTPSP) dan persepsi tentang biogas (2) menganalisis hubungan antara karakteristik RTPSP, persepsi peternak tentang biogas, akses informasi dan frekuensi pertemuan dengan penyuluh biogas dengan tingkat difusi-adopsi biogas.

\section{Metode Penelitian}

Peubahbebasyangditelitiyaitu(1)karakteristik RTPSP meliputi tingkat pendidikan formal, lama beternak, jumlah ternak, tingkat pendapatan, motivasi, dan luas lahan untuk biogas, (2) persepsi peternak tentang biogas meliputi keuntungan relatif, kompatibilitas, kompatibilitas, triabilitas dan observabilitas (3) akses terhadap informasi (4) frekuensi pertemuan dengan penyuluh biogas sedangkan peubah tidak bebas yaitu kecepatan dan penyebaran. Penelitian lapang di Desa Suntenjaya dan Desa Cibodas dilakukan dari bulan Maret 2014 sampai dengan Juni 2014. Seluruh peternak penerap biogas diambil sebagai responden (sensus). Secara lengkap jumlah populasi dan sampel dapat dilihat dari Tabel 1. Statistik deskriptif terdiri dari distribusi frekuensi, sedangkan statistik inferensial menggunakan analisis Rank Spearman dan uji beda U Mann Whitney.

\section{Hasil dan Pembahasan}

\section{Karakteristik Rumah Tangga Peternak Sapi}

\section{Perah (RTPSP)}

Tabel 2 memperlihtakan karakteristik RTPSP meliputi tingkat pendidikan formal, lama beternak, jumlah ternak, tingkat pendapatan, motivasi, dan luas lahan untuk biogas. Mayoritas tingkat pendidikan formal responden hanya sampai Sekolah Dasar (SD), ditempuh selama 6 tahun oleh 129 responden di Desa Suntenjaya dan sebanyak 115 responden di Desa Cibodas. Terdapat 4 responden atau sebanyak $1,5 \%$ yang menempuh pendidikan formal kurang dari 5 tahun hanya sampai kelas 3, kelas 4 dan kelas 5 SD (tidak tamat SD) dan sebanyak 11 responden berpendidikan SMP yang ditempuh selama 9 tahun serta sebanyak 7 responden berpendidikan SMA yang ditempuh selama 12 tahun.

Terdapat perbedaan tingkat pendapatan, sebanyak 93\% responden di Desa Suntenjaya berpendapatan rendah, sedangkan $93,6 \%$ responden di Desa Cibodas berpendapatan sedang dengan mayoritas responden bekerja sebagai peternak dan bekerja sampingan sebagai petani hortikultura. Pendapatan beternak diperoleh dari perahan susu sapi dengan harga Rp 4.100 per liter. Sebanyak $41,8 \%$ responden di Desa Suntenjaya hanya memiliki ternak kurang dari 3 ekor, sedangkan $42,4 \%$ responden memiliki ternak antara 4-5 ekor.

Dari segi luas lahan untuk biogas di dua desa penelitian terlihat berbeda, perbedaan ukuran reaktor biogas dan luas yang diperlukan untuk membangun instalasi biogas disesuaikan dengan luas lahan yang dimiliki oleh RTPSP, di Suntenjaya yang terdapat tiga ukuran reaktor biogas, di Desa Cibodas tidak ada reponden yang memiliki reaktor biogas dengan ukuran $5 \mathrm{~m}^{3}$.

\section{Persepsi tentang Sifat Inovasi Biogas}

Terdapatperbedaan persepsi tentang keuntungan relatif antara Desa Suntenjaya dan Desa Cibodas, di Desa Suntenjaya sebanyak 88 peternak atau

Tabel 1 Populasi Rumah Tangga Peternak Sapi Perah (RTPSP)

\begin{tabular}{clcc}
\hline No. & \multicolumn{1}{c}{ Desa } & Populasi RTSP & Populasi RTSP penerap biogas \\
\hline 1. & Suntenjaya & 420 & 141 \\
2. & Cibodas & 255 & 125 \\
\hline Jumlah & & 675 & 266 \\
\hline
\end{tabular}


Tabel 2 Distribusi Responden berdasarkan Karakteristik RTPSP]

\begin{tabular}{|c|c|c|c|c|c|}
\hline \multirow{2}{*}{ Sub Variabel } & \multicolumn{2}{|c|}{$\begin{array}{c}\text { Desa } \\
\text { Suntenjaya }\end{array}$} & \multicolumn{2}{|c|}{ Desa Cibodas } & \multirow{2}{*}{$\begin{array}{c}\text { Signifikansi } \\
\text { Uji beda Mann- Whitney U } \\
\end{array}$} \\
\hline & n & $\%$ & $\mathbf{n}$ & $\%$ & \\
\hline \multicolumn{6}{|l|}{$\begin{array}{l}\text { 1. Tingkat Pendidikan formal } \\
\text { (tahun) }\end{array}$} \\
\hline a. Rendah $(\leq 6)$ & 131 & 93,0 & 117 & 93,60 & \multirow{3}{*}{0,667} \\
\hline b. Sedang (7-12) & 9 & 6,3 & 2 & 0,16 & \\
\hline c. Tinggi $(\geq 13)$ & 1 & 0,7 & 6 & 4,80 & \\
\hline Total & 141 & 100,0 & 125 & 100,00 & \\
\hline \multicolumn{6}{|c|}{ 2. Jumlah ternak sapi perah (ekor) } \\
\hline a. Sedikit $(\leq 3)$ & 59 & 41,8 & 53 & 42,4 & \multirow{3}{*}{0,069} \\
\hline b. Sedang (4-5) & 39 & 27,6 & 50 & 40,0 & \\
\hline c. Banyak $(\geq 6)$ & 43 & 30,6 & 22 & 17,6 & \\
\hline Total & 141 & 100,0 & 125 & 100,0 & \\
\hline \multicolumn{6}{|l|}{ 3. Lama beternak (tahun) } \\
\hline a. Rendah $(\leq 9)$ & 56 & 39,7 & 29 & 23,2 & \multirow{3}{*}{0,371} \\
\hline b. Sedang (10-19) & 43 & 34,4 & 55 & 44,0 & \\
\hline c. Tinggi $(\geq 20)$ & 99 & 79,2 & 41 & 32,8 & \\
\hline Total & 141 & 100,0 & 125 & 100,0 & \\
\hline \multicolumn{6}{|c|}{ 4. Tingkat Pendapatan RTSP (per tahun) } \\
\hline $\begin{array}{l}\text { a. Rendah }(\leq 9828 \\
435.31)\end{array}$ & 81 & 57,4 & 2 & 0,16 & \multirow{3}{*}{$0,00 * *$} \\
\hline $\begin{array}{l}\text { b. Sedang (9 } 828435.32- \\
81932751)\end{array}$ & 50 & 35,4 & 115 & 92,00 & \\
\hline c. Tinggi ( $\geq 81932751.1)$ & 10 & 7,2 & 8 & 6,40 & \\
\hline Total & 141 & 100,0 & 125 & 100,00 & \\
\hline \multicolumn{6}{|l|}{ 5. Motivasi } \\
\hline a. Rendah & 6 & 4,3 & 6 & 4,8 & \multirow{3}{*}{0,23} \\
\hline b. Sedang & 86 & 60,9 & 48 & 38,4 & \\
\hline c. Tinggi & 49 & 34,8 & 68 & 54,4 & \\
\hline Total & 141 & 100,0 & 125 & 100,0 & \\
\hline \multicolumn{6}{|l|}{ 6. Luas lahan untuk biogas } \\
\hline a. Sempit $\left(4 \mathrm{~m}^{2}\right)$ & 98 & 69,5 & 41 & 32,8 & \multirow{3}{*}{$0,00 * *$} \\
\hline b. Sedang $\left(5 \mathrm{~m}^{2}\right)$ & 28 & 19,8 & 0 & 0,0 & \\
\hline c. Luas $\left(6 \mathrm{~m}^{2}\right)$ & 15 & 10,6 & 84 & 67,2 & \\
\hline Total & 141 & 100,0 & 125 & 100,0 & \\
\hline
\end{tabular}

Keterangan : ** Berbeda nyata pada $\alpha=0,01$

sebesar $62,4 \%$ menilai bahwa dengan menggunakan biogas dapat menghemat waktu dan tenaga. Selain itu terdapat 18 atau sebesar $12,7 \%$ responden menilai dengan menggunakan biogas hanya dapat menghemat waktu, karena responden memproses biogas sambil mengurus ternak di kandang. Seorang responden menilai dengan menggunakan biogas hanya dapat menghemat tenaga karena responden tidak perlu lagi mencari kayu di hutan untuk memasak.
Sebanyak 34 responden atau sebanyak 24,1\% yang menilai dengan menggunakan biogas tidak menghemat waktu dan tenaga, karena mereka tetap menggunakan kayu bakar dan LPG untuk memasak. Di Desa Cibodas, 58,4\% atau sebanyak 73 responden menilai dengan menggunakan biogas, dapat menghemat waktu dan tenaga. Sebanyak 20,8\% atau 26 responden, responden menilai dengan menggunakan biogas hanya dapat menghemat 
Tabel 3 Persepsi tentang Sifat Inovasi Biogas

\begin{tabular}{|c|c|c|c|c|c|c|}
\hline \multirow{2}{*}{ Peubah } & \multirow{2}{*}{ Kategori } & \multicolumn{2}{|c|}{ Desa Suntenjaya } & \multicolumn{2}{|c|}{ Desa Cibodas } & \multirow{2}{*}{$\begin{array}{c}\text { Uji beda } \\
\text { U Mann- } \\
\text { Whitney } \\
\text { Signifikans } \\
\end{array}$} \\
\hline & & $\mathbf{n}$ & $\%$ & $\mathbf{n}$ & $\%$ & \\
\hline \multirow{3}{*}{$\begin{array}{l}\text { Keuntungan } \\
\text { relatif }\end{array}$} & Rendah & 5 & 3,5 & 6 & 4,8 & $0,006^{* *}$ \\
\hline & Sedang & 89 & 63,1 & 61 & 48,8 & \\
\hline & Tinggi & 47 & 33,4 & 58 & 46,4 & \\
\hline Total & & 141 & 100 & 125 & 100,0 & \\
\hline \multirow[t]{3}{*}{ Kompleksitas } & Rendah & 82 & 58,1 & 82 & 65,6 & 0,914 \\
\hline & Sedang & 59 & 41,8 & 42 & 33,6 & \\
\hline & Tinggi & 0 & 0,0 & 1 & 0,8 & \\
\hline Total & & 141 & 100,0 & 125 & 100,0 & \\
\hline \multirow[t]{3}{*}{ Kompatibilitas } & Rendah & 1 & 0,7 & 1 & 0,8 & 0,956 \\
\hline & Sedang & 62 & 44,0 & 61 & 48,8 & \\
\hline & Tinggi & 78 & 55,3 & 63 & 50,4 & \\
\hline Total & & 141 & 100,0 & 125 & 100,0 & \\
\hline \multirow[t]{3}{*}{ Triabilitas } & Rendah & 1 & 0,7 & 6 & 4,8 & $0,014 * *$ \\
\hline & Sedang & 40 & 28,4 & 32 & 25,6 & \\
\hline & Tinggi & 100 & 70,9 & 87 & 69,6 & \\
\hline Total & & 141 & 100,0 & 125 & 100,0 & \\
\hline \multirow[t]{3}{*}{ Observabilitas } & Rendah & 6 & 4,2 & 8 & 6,4 & 0,536 \\
\hline & Sedang & 82 & 58,2 & 66 & 52,8 & \\
\hline & Tinggi & 53 & 37,6 & 51 & 40,8 & \\
\hline Total & & 141 & 100,0 & 125 & 100,0 & \\
\hline
\end{tabular}

Keterangan: $\quad * *$ Korelasi sangat nyata pada $\alpha=0,01$

waktu, karena mereka tidak memerlukan waktu untuk membeli bahan baka lain ataupun mencari kayu di hutan dan dapat memproses biogas sambil mengurus ternak sapi perah di kandang. Sebanyak $8 \%$ atau 10 peternak menilai bahwa dengan menggunakan biogas hanya dapat menghemat tenaga karena peternak tidak perlu lagi mencari kayu di hutan untuk memasak, serta sebanyak $12,8 \%$ atau sebanyak 16 peternak menilai dengan menggunakan biogas tidak menghemat waktu dan tenaga, karena butuh waktu untuk mengumpulkan feces sapi dan tenaga untuk mengangkut feces tersebut, serta mengambil air. Secara rinci persepsi tentang inovasi biogas disajikan dalam Tabel 3.

Mayoritas 56,4\% peternak menilai bahwa biogas cukup menguntungkan, 61,6\% peternak menilai biogas relatif sederhana, 53\% peternak menilai biogas sangat sesuai dengan kebutuhan peternak sekaligus mengurangi pencemaran sungai, dan $70,3 \%$ ketercobaan dinilai sangat mudah serta
$66,3 \%$ peternak menilai biogas cukup mudah teramati.

\section{Penerapan Biogas di Dua Desa Penelitian}

Biogas di dua desa penelitian mulai dirintis pada tahun 2006 dengan tipe plastik dan masih dalam taraf percobaan. Percobaan biogas di Desa Suntenjaya dilakukan oleh Yayasan Pengembangan Masyarakat (sebuah Lembaga Swadaya Masyarakat) sedangkan biogas Desa Cibodas dirintis oleh Dinas Peternakan Kabupaten Bandung Barat. Tidak terjadi penambahan adopter dari tahun 2006 hingga tahun 2009, karena percobaan menghasilkan tipe biogas plastik rentan rusak. Pada tahun 2010, program BIRU (Biogas Rumah) melalui KPSBU (Koperasi Susu Bandung Utara), mulai menambah adopter biogas. Pada tahun 2011 Desa Suntenjaya memperoleh bantuan sarana pembuatan biogas dari Dinas ESDM Jawa Barat sehingga semakin menambah RTPSP adopter inovasi biogas. 
Tabel 4 Distribusi RTPSP menurut Kecepatan Adopsi dan Difusi Biogas Tahun 2014

\begin{tabular}{|c|c|c|c|c|c|}
\hline \multirow{2}{*}{ Kategori } & \multicolumn{2}{|c|}{ Desa Suntenjaya } & \multicolumn{2}{|c|}{ Desa Cibodas } & \multirow{2}{*}{$\begin{array}{l}\text { Uji U Mann- } \\
\text { Whitney } \\
\text { Signifikansi }\end{array}$} \\
\hline & $\mathbf{n}$ & $\%$ & $\mathbf{n}$ & $\%$ & \\
\hline \multicolumn{6}{|l|}{ 1. Kecepatan } \\
\hline Rendah ( $\geq 4$ tahun) & 15 & 10,60 & 13 & 10,40 & \\
\hline Sedang (3 - 4 tahun) & 122 & 86,50 & 110 & 88,00 & 0,0692 \\
\hline Tinggi ( $\leq 2$ tahun) & 4 & 2,90 & 2 & 1,60 & \\
\hline Total & 141 & 100,00 & 125 & 100,00 & \\
\hline \multicolumn{6}{|l|}{ 2. Penyebaran } \\
\hline Rendah $(\leq 21,1 \%)$ & 25 & 17,70 & 28 & 22,40 & \\
\hline Sedang $(21,2 \%-47,20 \%)$ & 75 & 53,20 & 0 & 0,00 & $0,00 * *$ \\
\hline Tinggi $(\geq 47,23 \%)$ & 41 & 29,10 & 97 & 77,60 & \\
\hline Total & 141 & 100,00 & 125 & 100,00 & \\
\hline
\end{tabular}

Sampai saat ini sebesar 12,7\% RTPSP Desa Cibodas menggunakan biogas untuk kebutuhan memasak di dapur dan memasak air di kandang. Desa Cibodas mendapatkan 82 unit biogas gratis yang diberikan pada RTSP di Dusun Areng dan sisanya sebanyak 43 unit biogas dari BIRU yang tersebar di Dusun Cisarongge, Dusun Babakan Gentong, Dusun Cijero Kaso, dan Dusun Sukamaju. Biogas semakin berkembang tidak hanya karena bantuan gratis akan tetapi adanya kredit biogas dari KPSBU.

Di dua desa penelitian, kecepatan adopsi berada pada kategori sedang (skor 2) yaitu RTSP menerapkan inovasi biogas tiga sampai empat tahun tahun sejak penerapan pertama di tahun 2006. Penyebaran yang dilihat dari persentase rumahtangga peternak yang mengadopsi inovasi biogas dalam periode waktu (tahun) terlihat berbeda di dua desa penelitian karena di Desa Cibodas termasuk kategori tinggi (skor 3), terdapat lebih dari 47,23\% adopter dan berpusat di Dusun Areng dan tidak merata seperti di dusun-dusun di Desa Suntenjaya. Informasi tentang tingkat difusi-adopsi biogas dari sisi kecepatan dan penyebaran/difusi ditampilkan pada Tabel 4.

\section{Tingkat Difusi-Adopsi Inovasi Biogas}

Hasil uji korelasi Rank Spearman menunjukkan hubungan nyata antara motivasi, keuntungan relatif, kompleksitas, kompatibilitas dan observabilitas dengan peubah kecepatan adopsi, sedangkan lama beternak, keuntungan relatif serta triabilitas memiliki hubungan nyata dengan peubah penyebaran.

Lama beternak memiliki hubungan nyata dengan tingkat penyebaran di dua desa penelitian, namun tidak memiliki hubungan nyata dengan kecepatan mengadopsi. Pada awal penerapan biogas yaitu tahun 2006, biogas tidak berkembang di dua desa penelitian, dan hanya diadopsi oleh enam peternak tanpa disebarkan ke peternak lain, namun pada tahun 2011 peternak adopter juga mengajak peternak lain untuk menerapkan biogas, karena melihat reaktorbiogas yang semakin berkembang dari tipe plastik yang lebih rentan rusak hingga sekarang menggunakan reaktor tipe beton (fixed dome) yang lebih awet dibanding tipe plastik. Motivasi memiliki hubungan sangat nyata dengan kecepatan menerapkan biogas, hal ini dikarenakan motivasi intrinsik maupun ekstrinsik yang berhubungan dengan kecepatan RTPSP menerapkan inovasi biogas. Hal tersebut juga sesuai dengan hasil penelitian Tondok et al. (2011) yang menemukan bahwa motivasi berhubungan sangat nyata dengan tingkat penerapan teknologi, semakin tinggi motivasi petani semakin tinggi tingkat penerapan teknologi. Di sisi lain, motivasi tidak memiliki hubungan yang signifikan dengan penyebaran karena peternak yang hanya termotivasi menerapkan biogas tanpa termotivasi untuk mengajak peternak lain menerapkan biogas. Secara rinci hubungan antar berbagai faktor dengan tingkat difusi-adopsi biogas dapat dilihat dalam Tabel 5.

Dari segi persepsi tentang sifat inovasi, hanya keuntungan relatif dan triabilitas yang memiliki 
Tabel 5 Hubungan Peubah Karakteristik RTPSP, Persepsi tentang Sifat Inovasi dan Akses Informasi serta Frekuensi Pertemuan dengan Penyuluh Biogas dengan Tingkat Difusi-Adopsi Inovasi Biogas

\begin{tabular}{llcc}
\hline No & \multicolumn{1}{c}{ Peubah (X) } & Kecepatan (Y1) & Penyebaran (Y2) \\
\hline 1 & Tingkat Pendidikan Formal & 0,081 & $-0,072$ \\
2 & Lama beternak & 0,120 & $0,269^{* *}$ \\
3 & Jumlah Ternak & 0,071 & $-0,047$ \\
4 & Tingkat Pendapatan RTPSP & 0,065 & 0,113 \\
5 & Motivasi & $0,181^{* *}$ & $-0,044$ \\
6 & Luas lahan untuk biogas & 0,018 & 0,072 \\
7 & Keuntungan Relatif & $0,204^{* *}$ & $0,151^{*}$ \\
8 & Kompleksitas & $0,148^{*}$ & 0,013 \\
9 & Kompatibilitas & $0,132^{*}$ & $-0,041$ \\
10 & Triabilitas & 0,029 & $0,133^{*}$ \\
11 & Observabilitas & $0,236^{*}$ & $-0,058$ \\
12 & Akses informasi inovasi biogas & 0,068 & 0,094 \\
13 & Frekuensi pertemuan dengan penyuluh biogas & 0,070 & 0,095 \\
\hline
\end{tabular}

Keterangan: $\quad *$ Korelasi nyata pada $\alpha=0,05$

**Korelasi sangat nyata pada $\alpha=0,01$

hubungan nyata dengan tingkat penyebaran, hal ini berarti bahwa individu peternak mengadopsi biogas tidak hanya untuk dirinya sendiri tetapi juga menyebarkan kepada peternak lain. Hal ini sejalan Hal ini sejalan dengan penelitian Roswida (2003) bahwa keuntungan relatif berhubungan dengan pengambilan keputusan dalam memilih inovasi teknologi pertanian. Persepsi peternak yang baik terhadap biogas sebagai energi alternatif sehingga peternak cepat menerapkan dan mampu untuk menyebarluaskan (difusi) kepada peternak lain disekitar tempat tinggalnya masing-masing (Tri Rahayu et al., 2013).

Berdasarkan keuntungan relatif, konsumsi bahan bakarmemasak, jika duluRTPSPmembutuhkan 2 tabung gas LPG (3kg) seharga Rp 21.000 per tabung untuk memasak. Jika sebulan membutuhkan 2 tabung LPG seharga Rp 21.000 untuk memasak maka sehari membutuhkan biaya $\mathrm{Rp} 1.400$. Dengan biogas maka peternak menghemat Rp 1.400 per hari, ataupun jika masih menggunakan 1 tabung LPG maka RTSP juga tetap menghemat Rp 700 per harinya. Hal ini sejalan dengan penelitian Mwirigi et al. (2009) menyatakan bahwa difusi inovasi sangat memerlukan pengenalan inovasi tersebut kepada adopter dan juga disesuaikan dengan kondisi lingkungan adopter sehingga adopter dapat melihat keuntungan dari inovasi tersebut. Peternak menerapkan biogas dengan melihat segi keuntungan dan kesesuaian dengan kebutuhan (Song et al., 2014).

Dari sisi difusi biogas di dua desa penelitian tampak bahwa peranan early adopter sangat penting, karena early adopter mencakup ketua kelompok ternak yang berpengaruh untuk memepercepat difusi biogas di kalangan peternak. Pada tahun 2010 hingga 2011 di Desa Suntenjaya terdapat 16 responden atau sebanyak 15,4\% sebagai early adopter, sedangkan di Desa Cibodas sebanyak terdapat 11 responden atau sebanyak 4,3\% sebagai early adopter. Lebih lanjut pada tahun 2012 terjadi penambahan jumlah adopter di Desa Suntenjaya 117 atau sebanyak 27,8\% adopter, sedangkan di Desa Cibodas sebanyak 96 responden atau 37,6\% dan 78 responden menyatakan termotivasi karena mengikuti ajakan dari ketua kelompok ternak, tokoh masyarakat serta peternak lain yang terlebih dahulu menerapkan biogas.

Hasil uji menunjukkan tidak terdapat hubungan nyata antara akses informasi inovasi biogas dan frekuensi pertemuan dengan penyuluh biogas dengan tingkat difusi-adopsi biogas. Akses informasi biogas belum sesuai dengan kebutuhan peternak karena informasi tentang biogas hanya mengenai cara memproses biogas tanpa menjelaskan cara perawatan biogas, hal ini sejalan dengan Hosen (2012) bahwa informasi teknologi harus sesuai dan dipahami oleh peternak sehingga peternak 
memahami cara pemrosesan biogas dan perawatan instalasi biogas.

Frekuensi pertemuan dengan penyuluh biogas berada dalam kategori rendah (kurang dalam sekali sebulan). Kunjungan penyuluh dari Dinas maupun dari penyuluh biogas KPSBU kurang dari sekali dalam sebulan. Peternak penerap biogas kredit dari KPSBU yang dikunjungi oleh penyuluh biogas dari KPSBU dan petugas perbaikan unit biogas. Penyuluh harusnya dapat berperan sebagai fasilitator dalam program biogas, namun dalam pertemuan dengan penyuluh belum berpola penyuluhan dalam konteks transformasi perilaku. Penyuluh perlu lebih banyak menerapkan prinsip membantu orang lain agar orang tersebut dapat membantu dirinya sendiri (help people to help themselves). Diperlukan dukungan dari penyuluh/fasilitator yang menguasai pendekatan dan kemampuan teknis tentang biogas dalam memotivasi peternak untuk menerapkan dan menyebarluaskan inovasi biogas di masyarakat.

\section{Kesimpulan}

Simpulan penelitian adalah: (1) Biogas layak diterapkan menurut persepsi RTPSP namun tingkat adopsi biogas masih di bawah 50\% (2) Semakin banyak peternak termotivasi menerapkan biogas, peternak menilai biogas menguntungkan, biogas tidak rumit, sangat sesuai kebutuhan dan sangat mudah dicoba maka peternak lebih cepat mengadopsi biogas, sedangkan lamanya beternak, peternak yang menilai biogas menguntungkan, dan mudah dicoba maka difusi semakin tinggi (3) Akses terhadap informasi dan frekuensi pertemuan dengan penyuluh biogas perlu disesuaikan kebutuhan peternak. Sampai saat ini, peternak lebih banyak memperoleh pendampingan dari program biogas yang didukung oleh organisasi internasional.

\section{Daftar Pustaka}

Abbasi T. 2011. Biogas Energy. New York: Springer. Humayun K. 2013. Factors Determinant of Biogas Adoption in Bangladesh. Journal Renewable and Sustainable Energy Reviews, Volume 28, December 2013, Pages 881-889. http://www. sciencedirect.com [diunduh 29 Desember 2013].

Husein N. 2012. Adopsi Teknologi Pengolahan Limbah Pertanian oleh Petani Anggota
Gapoktan Puap di Kabuapaten Agam, Sumatera Barat. Jurnal Penelitian Pertanian Terapan 12 (2): 89-95 [diunduh 10 Juli 2014].

Mwirigi WJ, Makenzi P, Ochola W. 2009. Socioeconomic Constraints to Adoption and Sustainability of Biogas Technology by Farmers in Nakuru Districts, Kenya. Journal Energy for Sustainable Development. 13(2), June 2009. [Internet]. [dapat diunduh dari: http://www. sciencedirect.com].

Rogers E. 2003. Diffusion of Innovations Fifth edition. New York: The Free Press.

Roswida R. 2003. Tahapan Proses Keputusan Adopsi Inovasi Pengendalian Hama dan Penyakit Tanaman dengan Agen hayati (Kasus Petani Sayur di Kecamatan Banuhampu dan Sungai Puar kabupaten Agam Sumatera Barat. [tesis]. Bogor (ID): Institut Pertanian Bogor.

Zilin S, Zhang C, Yang G, Feng Y, Ren G, Han X. 2014. Comparison of Biogas Development from Households and Medium And Large-Scale Biogas Plants in Rural China. Journal Energy for Sustainable Development. 33: 204-213. [Internet]. [dapat diunduh dari: http://www. sciencedirect.com].

Tondok AR, Mappigau P, Kaimuddin. 2011. Pengaruh Motivasi, Modal Sosial dan Peran Model Terhadap Adopsi Teknologi PTT Cabai di Kabupaten Maros. [tesis].Universitas Hasanudin.

Tri RE, Emawati S, Nugroho Sapu I. 2013. Persepsi Masyarakat Terhadap Biogas Sebagai Energi Alternatif yang Ramah Lingkungan di Kecamatan Selo, Kabupaten Boyolali. Prosiding Seminar Nasional 2013 Menuju Masyarakat Madani dan Lestari ISBN: 978-979-98438-8-3. Wahyuni S. 2011. Menghasilkan Biogas dari Aneka Limbah. Jakarta (ID): Agro Media Pustaka.

Wei Qu, Qin T, Bluemling B. 2013. Which Factors are Effective for Farmers' Biogas Use? Evidence from a Large-Scale Survey in China. Journal Energy Policy. 63: 26-33. [diunduh 29 November 2013].

Yusriadi. 2011. Adopsi Teknologi Biogas oleh Peternak Sapi Perah Peternak di Kabupaten Enrekang, Sulawesi Selatan. Tesis. Bogor (ID): Institut Pertanian Bogor. 